\title{
A cross-sectional study to find the prevalence of hyperprolactinemia in infertile euthyroid patients in a hospital
}

\author{
Sanjay Badesara ${ }^{1}$, Kiran Jakhar ${ }^{2 *}$ \\ ${ }^{1}$ Department of Surgical Oncology, Delhi State Cancer Institute, Delhi, India \\ ${ }^{2}$ Department of Psychiatry, Government Institute of Medical Sciences, Greater Noida, Uttar Pradesh, India
}

Received: 22 September 2020

Accepted: 06 October 2020

*Correspondence:

Dr. Kiran Jakhar,

E-mail: kjakhar48@gmail.com

Copyright: $\odot$ the author(s), publisher and licensee Medip Academy. This is an open-access article distributed under the terms of the Creative Commons Attribution Non-Commercial License, which permits unrestricted non-commercial use, distribution, and reproduction in any medium, provided the original work is properly cited.

\section{ABSTRACT}

Background: Infertility whether primary or secondary, has multi-factorial causation, out of which hormonal imbalance is one of the important factors. Current study evaluates the prevalence of hyperprolactinemia in infertile euthyroid women.

Methods: After Ethics Committee approval and written informed consent, all infertile euthyroid women ( $\mathrm{n}=153)$ with age group 20-40 years attending outpatient department of general hospital, with marriage duration of at least one year and willing to participate in study were recruited. Male factor infertility, women with diagnosed hyperprolactinemia, thyroid abnormality, tubal factors, any congenital anomaly of urogenital tract or obvious organic lesion or with history of anxiety or other psychological disorders and on treatment for same were excluded. Detailed obstetrics history with relevant laboratory, radiological investigations including serum prolactin level was done.

Results: Mean serum prolactin level was $13.89 \pm 10.03 \mathrm{ng} / \mathrm{ml}$. Out of 153 participants, 13 had hyperprolactinemia which comprised $8.50 \%$ of the sample. The mean of the level of serum prolactin level in primary infertility cases was $13.18 \pm 8.485 \mathrm{ng} / \mathrm{ml}$ while that in secondary infertility was $17.21 \pm 15.1 \mathrm{ng} / \mathrm{ml}$. Primary infertility was approximately half $(53.85 \%)$ in hyperprolactinemia group and majority $(85 \%)$ in normoprolactinemia group. Duration of married life, infertility and fasting blood sugar were positively correlated with prolactin levels.

Conclusions: Prevalence of hyperprolactinemia was $8.50 \%$ with higher serum prolactin level in secondary infertility as compared to primary infertility. So, estimation of serum prolactin levels in infertile patients with euthyroid status can help to a large extent in finding the cause of infertility and may help in further management.

Keywords: Infertility, Hyperprolactinemia, Euthyroid

\section{INTRODUCTION}

Infertility is a disease of the reproductive system defined by the failure to achieve a clinical pregnancy after 12 months or more of regular unprotected sexual intercourse (WHO 1975, 2001). ${ }^{1}$ According to World Health Organization (WHO) in developing countries one out of 4 couples is suffering from infertility, with a burden of 2223 million infertile couples in India. ${ }^{2,3}$ Infertility may be primary if participation of either partner does not turn out to be successful in achieving pregnancy or secondary if couple has achieved a pregnancy previously but are having difficulty with conception currently.,5 Various hormones play an important role in the reproduction, so estimation of these hormones are important in the infertility workup, especially prolactin and thyroid hormones including thyroid stimulating hormone (TSH). ${ }^{4}$ Normal levels of prolactin range between 5 and $27 \mu \mathrm{g} / 1$ for women and between 5 and $15 \mathrm{ug} / \mathrm{l}$ for men. Hyperprolactinemia adversely affects fertility potential by impairing pulsatile gonadotropin releasing hormone $(\mathrm{GnRH})$ secretion and hence interfering with ovulation. ${ }^{7,8}$ Menstrual and ovulatory dysfunction like anovulation, amenorrhoea and galactorrhoea are associated with 
increase in prolactin level. ${ }^{9,10}$ High prolactin levels may also interfere with estrogen and progesterone production. Hyperprolactinemia can stop ovulation altogether. ${ }^{11}$

Although both prolactin and thyroid hormones play an imminent role in reproduction and both of them effect the regulation of each other, there are studies which have shown that prolactin hormone independently has impact on the fertility of a female. So the current study was undertaken to establish the prevalence of hyperprolactinimia in euthyroid infertile females and also to look for the association of hyperprolactinemia with various clinical and socio-demographic variables.

\section{METHODS}

A total of 153 infertile women of age group 20-40 years attending outpatient department (OPD) of West Indian hospital serving rural population mainly were recruited in the study during study period (January 2015 to December 2015).

Inclusion criteria included women with duration of marriage at least one year or more and with, infertile euthyroid status attending study site during study period. Subjects of age group 20 to 40 years were included in the study. Exclusion criteria were; subjects with age $<20$ years and $>40$ years, male factor infertility in partner, amongst female factors tubal factors, with ovulatory dysfunctions, any congenital anomaly of urogenital tract or any obvious organic lesion, women with diagnosed hyperprolactinemia or thyroid abnormality, tuberculosis and women with history of anxiety disorders and other psychological disorders and on drug treatment for the same.

Written informed consent was taken from the participants recruited in the study. Sample size of 153 was calculated after fixing confidence level of $95 \%$ and assuming standard deviation of $18.9 \mathrm{ng} / \mathrm{ml}$ as found in the study by Goswami et al with absolute allowable error (precision) of $3 \mathrm{ng} / \mathrm{ml}$ in serum prolactin level, sample size is calculated by following formula; ${ }^{2}$

Sample size $(\eta)=\frac{\mathrm{Z} \alpha^{2} \mathrm{P} \times \mathrm{q}}{L^{2}}$

Where $z \alpha=1.96, \mathrm{P}=18.9, \mathrm{q}=(100-\mathrm{p})=81.1, \mathrm{~L}=3$.

\section{Assessment procedure}

Ethics committee approval was taken at the outset. All participants presenting with infertility were informed about the study and written informed consent was taken. They were screened for their thyroid status. Euthyroid participants fulfilling inclusion criteria and who did not have any exclusion criteria were recruited and their detailed history including obstetric history was taken. Relevant samples of all the participants were subjected for laboratory, radiological and other special investigations including serum prolactin level.

Diurnal variation on serum prolactin level was minimized by taking early morning sample at fixed hours of 8 a.m. to 9 a.m. Serum prolactin levels also changes with physical examination (nipple stimulation, intercourse, breast examination), so participants were instructed for nil per-orally from the night before and avoid stimulation of breast, nipple and intercourse from day before and on the day on which sample was to be taken. Breast examination was also avoided. Psychological stress increases serum prolactin level but the present study did not look into this aspect as this could be evaluated by a trained Psychiatrist. Serum prolactin level of the participants was recorded which was assayed by competitive enzyme linked immune sorbent assay (ELISA) using commercially available kit (accubind ELISA micro wells).

\section{Statistical analysis}

Data thus collected was entered in excel sheet to prepare master chart and was subjected to statistical analysis. Continuous variables were summarized as mean and standard deviation while nominal/categorical variables as proportions (\%). Unpaired t test and one way analysis of variance (ANOVA) test were used for continuous variables, whereas chi square test and other non parametric tests were used for nominal/ categorical variables as per data yield. $\mathrm{p}<0.05$ was taken as significant. Medcalc 14.0.0 version software was used for all statistical analysis.

\section{RESULTS}

The mean age of sample was $26.38 \pm 3.95$ years with mean menarche age of $12.84 \pm 0.69$ years (Table 1). The mean serum prolactin level of the sample was $13.89 \pm 10.03$ $\mathrm{ng} / \mathrm{ml}$. The mean age of marriage was $21.32 \pm 2.54$ years with mean married life of $5.13 \pm 3.16$ years. The mean duration of infertility was $4.30 \pm 3.16$ years. The mean BMI of the sample was $21.88 \pm 4.26 \mathrm{~kg} / \mathrm{m}^{2}$.

Table 1: Clinical characteristics of cases $(n=153)$.

\begin{tabular}{|lll|}
\hline Characteristics & Mean & $\begin{array}{l}\text { Standard } \\
\text { deviation }\end{array}$ \\
\hline Serum prolactin (ng/ml) & 13.89 & 10.03 \\
\hline Age (years) & 26.38 & 3.95 \\
\hline Menarche age (years) & 12.84 & 0.69 \\
\hline Age at marriage (years) & 21.32 & 2.54 \\
\hline Married life (years) & 5.13 & 3.65 \\
\hline Duration of infertility (years) & 4.30 & 3.16 \\
\hline BMI (kg/m $\mathbf{m}^{\mathbf{2}}$ & 21.88 & 4.26 \\
\hline
\end{tabular}

Out of 153 euthyroid participants suffering from infertility, 13 had hyperprolctinemia which comprises 
$8.50 \%$ of the sample. Rest 140 cases had normal prolactin levels comprising $91.50 \%$ of the sample (Table 2).

Table 2: Prevalence of hyperprolactinemia in infertile euthyroid participants.

\begin{tabular}{|ll|}
\hline Prolactin & $\mathbf{N}(\%)$ \\
\hline Hyperprolactinemia & $13(8.5)$ \\
\hline Normoprolactinemia & $140(91.50)$ \\
\hline Total & $153(100)$ \\
\hline
\end{tabular}

In hyperprolactinemia group approximately half of patients $(53.85 \%)$ had primary infertility while $46.15 \%$ had secondary infertility. Although in normoparolactinemia group $85 \%$ had primary infertility while $15 \%$ had secondary infertility (Table 3 ).

Table 3: Distribution according to hyperprolactinemia and type of infertility.

\begin{tabular}{|llll|}
\hline $\begin{array}{l}\text { Type of } \\
\text { infertility }\end{array}$ & $\begin{array}{l}\text { Hyperpro } \\
\text { lactinemc } \\
\text { women }\end{array}$ & $\begin{array}{l}\text { Normopro } \\
\text { lactinemic } \\
\text { women }\end{array}$ & Total \\
\hline N (\%) & $\mathbf{N}(\%)$ & N (\%) \\
\hline Primary & $7(53.85)$ & $119(85)$ & $126(82.35)$ \\
\hline Secondary & $6(46.15)$ & $21(15)$ & $27(17.65)$ \\
\hline Total & $13(100)$ & $140(100)$ & $153(100)$ \\
\hline
\end{tabular}

*Chi Square, 5.945; degree of freedom, $1 ; \mathrm{p}=0.015$

The mean serum prolactinlevel in primary infertility participants was $13.18 \pm 8.485 \mathrm{ng} / \mathrm{ml}$ while that in secondary infertility was $17.21 \pm 15.1 \mathrm{ng} / \mathrm{ml}$ (Table 4).

Table 4: Comparison of level of serum prolactin (ng/ml) according to type of infertility.

\begin{tabular}{|lllll|} 
Infertility & $\begin{array}{l}\text { Number } \\
\text { of } \\
\text { women }\end{array}$ & Mean & $\begin{array}{l}\text { Standard } \\
\text { deviation }\end{array}$ & P value* \\
\hline Primary & 126 & 13.18 & 8.485 & 0.057 \\
\hline Secondary & 27 & 17.21 & 15.1 & \\
\hline
\end{tabular}

*Unpaired t test

\section{DISCUSSION}

The present study aimed to find the effect of prolactin on the fertility of females when the thyroid status within normal range. There is literature regarding the various mechanisms related to the effect of prolactin and thyroid hormones on fertility. So the present study tried to find the independent relationship of prolactin hormone with fertility. The present studies recruited 153 participants and were screened for thyroid status. All the sociodemographic and clinical parameters were included. Only euthyroid participants were recruited, following which their serum prolactin level was measured using standard protocol. We assessed the prevalence of hyperprolactinemia in euthyroid infertile females and its correlates with socio-demographic and clinical variables.

\section{Prevalence of hyperprolactinemia}

Out of 153 euthyroid participants suffering from infertility, 13 had hyperprolactinemia which comprises $8.5 \%$ of the sample. So the prevalence of hyperprolactinemia in the present study was $8.5 \%$. Rest 140 participants had normal prolactin levels comprising $91.50 \%$ of the sample. Study by Tasneem et al reported the prevalence of hyperprolactinemia of $4.90 \%$ and it included both male and females infertile patients with $22.7 \%$ patients having hypothyroidism in hyperprolactinemia group. ${ }^{13}$

Similarly study by Hooja et al also reported the prevalence of hyperprolactinemia of $27.5 \%$ in 80 infertile patients with hypothyroidism. Sharma et al in reported hyperprolactinemia in $32 \%$ infertile females, where majority were euthyroid although few patients had hypothyroidism but it included both fertile and infertile patients. ${ }^{14,15}$

A study by Goswami et al depicted hyperprolactinemia in $41 \%$ of infertile females and infertile women with hypothyroidism had significantly higher prolactin levels. A study by Akhter and Hassan et al reported hyperprolactinemia was prevalent in $43 \%$ of primary infertile females and $21 \%$ in secondary infertile females with hypothyroidism of $6.5 \%$ and $15 \%$ in the respective group. The findings of the present study are not in consonance with the studies in which the prevalence of hyperprolactinemia was either higher or lower in comparison to the present one. This disconcordance might be due to the fact that all these studies had mixed sample where hypothyroidism as confounding factor and we had pure sample of euthyroid infertile women. ${ }^{12,16}$

\section{Distribution of cases according to hyperprolactinemia and type of infertility}

In hyperprolactinemia group, approximately half $(53.85 \%)$ of the participants had primary infertility while in normoprolactinemia group, majority $(85 \%)$ had primary infertility as compared to $15 \%$ who had secondary infertility. Comparison of level of serum prolactin $(\mathrm{ng} / \mathrm{ml})$ according to type of infertility. The mean serum prolactin level in primary infertility participants was $13.18 \pm 8.485 \mathrm{ng} / \mathrm{ml}$ while that in secondary infertility was $17.21 \pm 15.1 \mathrm{ng} / \mathrm{ml}$ which shows that females suffering from secondary infertility had higher levels of serum prolactin level.

However, Akhter et al reported the mean prolactin level in primary infertility $(495 \pm 340 \mathrm{nmol} / \mathrm{l})$ to be higher than in secondary infertility $(340 \pm 310 \mathrm{nmol} / \mathrm{l})$, showing a significant statistical difference $(\mathrm{p}<0.05) .{ }^{16}$ The difference in findings might be attributed to the inclusion of subclinical thyroid disorders including both hypothyroidism and hyperthyroidism. 


\section{Correlations with serum prolactin}

Pearson correlation of serum prolactin level with various socio-demographic and clinical variables showed that only duration of married life, duration of infertility and fasting blood sugar were positively correlated.

\section{CONCLUSION}

In the present study, we concluded that the mean age of the sample was 26.38 years. The mean serum prolactin level of the sample was $13.89 \mathrm{ng} / \mathrm{ml}$. Out of 153 euthyroid participants suffering from infertility, 13 had hyperprolactinemia. So the prevalence of hyperprolactinemia in the present study was $8.50 \%$. In hyperprolactinemia group, approximately half $(53.85 \%)$ had primary infertility while in normoprolactinemia group; majority (85\%) had primary infertility as compared to $15 \%$ who had secondary infertility. The mean serum prolactin level in primary infertility cases was $13.18 \mathrm{ng} / \mathrm{ml}$ while that in secondary infertility was $17.21 \mathrm{ng} / \mathrm{ml}$ which shows that females suffering from secondary infertility had higher levels of serum prolactin level. So, the estimation of serum prolactin levels in infertile patients with euthyroid status could be of great benefit as it is elevated in significant number and treatment of the same could bring fruitful results, though more prospective data required for drawing a definite conclusion.

\section{ACKNOWLEDGMENTS}

We acknowledge all participants who consented to be a part of our study and the Institution for their kind cooperation in the making of this article and its submission.

\section{Funding: No funding sources}

Conflict of interest: None declared

Ethical approval: The study was approved by the Institutional Ethics Committee

\section{REFERENCES}

1. Zegers-Hochschild F, Adamson GD, de Mouzon J, Ishihara O, Mansur R, Nygren K, et al. International committee for monitoring assisted reproductive technology (ICMART) and the World Health Organization (WHO) revised glossary of ART terminology. Fertil Steril. 2009;92(5):1520-4.

2. Global status report on noncommunicable diseases 2014. Available at: http://www.who.int/nmh/ publications/ncd-status-report-2014/en/. Accessed on 20 August 2020.

3. National Family health survey, India. Available at:
http://rchiips.org/NFHS/factsheet_NFHS-4.shtml.

Accessed on 20 August 2020.

4. Osman AA. Management of infertility within primary health care program in Sudan. Asian J Sci Res. 2011;4(2):158-64.

5. Turankar S, Sonone K, Turankar A. Hyperprolactinaemia and its comparision with hypothyroidism in primary infertile women. J Clin Diagn Res. 2013;7(5):794-6.

6. Nallusamy S, Gracelyn LJ. Prevalence of hyperprolactinemia in infertile women and its association with hypothyroidism. Int $\mathrm{J}$ Adv Med. 2016;3(1):33-8.

7. Davis LB, Lathi RB, Dahan MH. The effect of infertility medication on thyroid function in hypothyroid women who conceive. Thyroid. 2007;17:773-7.

8. Poppe K, Velkenier B, Glinoer D. Thyroid disease and female reproduction. Clin Endocrinol (Oxf). 2007;66:309-21.

9. Onal ED, Saglam F, Sacikara M, Ersoy R, Cakir B. Thyroid autoimmunity in patients with hyperprolactinemia: An observational study. Arq Bras Endocrinol Metabol. 2014;58:48-52.

10. Wang AT, Mullan RJ, Lane MA, Hazem A, Prasad C, Gathaiya NW, et al. Treatment of hyperprolactinemia: A systematic review and metaanalysis. Syst Rev. 2012;1:33.

11. Kaiser UB. Hyperprolactinemia and infertility: new insights. J Clin Invest. 2012;122(10):3467-8.

12. Goswami B, Patel S, Chatterjee M , Koner BC, Saxena A. Correlation of Prolactin and Thyroid hormone concentration with menstrual patterns in Infertile women. J Reprod Infertil. 2009;10(3):20712.

13. Tasneem A, Fatima I, Ali A, Mehmood N, Amin MK. The incidence of hyperprolactinaemia and associated hypothyroidism: local experience from Lahore. Pak J Nucl Med. 2011;1:49-55.

14. Hooja N, Fatima A, Mital P, Singh N, Gothwal S, Aseri $\mathrm{S}$, et al. Correlation of prolactin and thyroid hormone levels in infertile women. Sch Acad J Biosci. 2015;3(1A):1-2.

15. Sharma P, Prasad S, Tangri N. Female infertility and its correlation with serum prolactin and $\mathrm{TSH}$ concentration- an unmatched case control study. J Pharm Biomed Sci. 2013;30(30):902-7.

16. Akhter N, Hassan S. Sub-clinical hypothyroidism and hyperprolactinemia in infertile women: Bangladesh persepective after universal salt iodination. Int J Endocrinol. 2008;5:1-8.

Cite this article as: Badesara S, Jakhar K. A crosssectional study to find the prevalence of hyperprolactinemia in infertile euthyroid patients in a hospital. Int J Reprod Contracept Obstet Gynecol 2020;9:4394-7. 